\title{
Journal of Sustainable Development of Transport and Logistics
}

journal home page: https://jsdtl.sciview.net

\section{Analysis of road transportation infrastructure construction and maintenance for sustainable development in South-Western Nigeria}

\section{Olusegun Onifade Adepoju}

Department of Maritime Transport Studies, Maritime Academy of Nigeria, Oron, Akwa Ibom State, Nigeria P.M.B 1089, Oron 523118, Akwa Ibom State, Nigeria adeseg001@yahoo.com

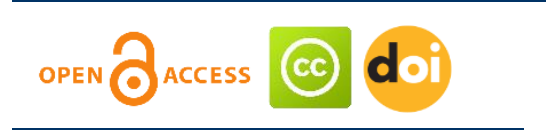

Article history:

Received: January 19, 2021

1st Revision: March 06, 2021

Accepted: April 14, 2021

\section{DOI:}

10.14254/jsdtl.2021.6-1.4
Abstract: The approaches to managing our road transportation infrastructure are not sustainable. A sustainable road transport infrastructure must meet the needs of present road users and give allowance to accommodate future developments. There is a gap between expected life span of roads in Nigeria and actual life span after putting the infrastructure into use. This paper examined the reasons government cannot repair roads in Nigeria, identify the challenges faced by the construction companies while on road construction projects and the effects of bad roads on national sustainable development. Ministry of Works and Transport, Ibadan and ad hoc staff of two major construction companies Reynolds Construction Company (RCC) and China Civil Engineering Construction Corporation (CCECC) were purposively selected based on the number of roads they have constructed in South-western Nigeria. Principal Component Analysis was used to identify the various factors that are responsible for the inability of government to construct and repair roads. Descriptive analysis was used to explain the challenges of construction companies and also the effects of bad road on national development. The findings identified 20 factors that are responsible for the inability of government to construct and maintain roads which were reduced into eight components. Some challenges in road construction are erosion, inadequate skilled labour, capital for equipment, funding, user's problem and machinery repairs. The effects of bad roads include: road crashes (27\%), high vehicle maintenance cost (21\%), capital flight (17\%), passengers' discomfort (14\%), high transportation cost $(11 \%)$ and drivers' fatigue $(10 \%)$. The study concluded that, there should be standardized procedure for road construction projects in the form of: penalty for failure to meet the required deadline, quality, usage and rehabilitation in order to achieve sustainable development. 
Keywords: road transport, infrastructure, construction, maintenance, Nigeria.

\section{Introduction}

Roads are very important in tapping resources, connecting people, places and businesses together. According to Filani (1999), Nigeria has the largest road network in West Africa with about $200,000 \mathrm{~km}$ surfaced roads. It is only about $28,980 \mathrm{~km}$ that were paved and $179,220 \mathrm{~km}$ unpaved (Federal Ministry of Works Bulletin, 2012). Hamzat (2016) observed that, Petroleum Trust Fund was initiated for road construction and maintenance between 1996 and 1999. However, it was further noted that roads were not properly constructed and there were no maintenance management systems in place to for sustainable development in Nigeria. Many roads constructed in the 1970s had not being repaired for once (CBN, 2002). In the South-western part of Nigeria, Lagos- Ibadan highway and Ibadan - Ogbomoso for instance were given to contractors and within the space of five years, the roads are very bad. According to Ezenwa (1986), the Nigerian roads are faced with the problem of design specifications and function below required standards. Ajani (2001) expressed that, the problem of road transportation is further compounded by different successive government

Road transport is a critical infrastructure for sustainable development as its efficiency is related consumption, distribution and production (Somuyiwa \& Olusegun, 2020). According to National Planning Commission (2018), the structure of road maintenance and management is among the three tiers of government viz: Federal, State and Local Government. Regrettably, local governments that used to be responsible for arterial routes and Trunk C roads' had since failed to perform their responsibility perhaps as they are now taking orders from State governments. The reason for this is because, subservience of Local governments under the State connotes they do not have autonomy. The Nigerian road transport is the one of the overstressed mode of transport infrastructures in Nigeria and this partly due to inadequate and inefficient services of other complementing modes of transport services. Okunlola (2018) noted that, Federal Road Maintenance Agency (FERMA) was established to monitor and rehabilitate federal roads in Nigeria but, they lack the funding, equipment, innovation and motivation to execute their jobs. Sally and Natalya (2005) said that postponing maintenance or construction cost increases both direct and indirect costs. If defect on the road is noticed and neglected; the entire section of the road may fail completely and require re-construction at three times or more of the initial cost. SANRAL (2004) explained that repair cost for road construction rises to six times the maintenance cost when you neglect road maintenance for three years and eighteen times after five years of neglect. Walter (2016)] observed that, the damage to Nigerian roads always start from cracking, potholes either by the edge of the road or at the center. Sustainable development according UNCTAD (2017) is connected with having long term food security, energy generation, human settlement, climate change, health system, transport system and other infrastructures. There is an expected level of road transport development which has not been realized for sustainable social, political and economic development of south-western Nigeria. Danladi et al (2013) expressed that performance of Nigerian roads is yet to be satisfactory in spite of several efforts to make it so.

\section{Theoretical underpinnings}

\section{Concept of sustainable transport}

According to Holden (2007), sustainable transport is related to a transport system whereby there is more efficient use of conventional transport technology, the idea of using alternative fuels, environmental friendly transport systems and making use of land-use planning systems. Sustainable road construction tends to revolve round engineering, technology and policy. Engineering seeks to find a sustainable method of durable road construction with a view to looking at the materials, designs and maintenance systems. Technology may be in form of using alternative methods to detecting structural failure and the use of information technology for highway management in the areas like: bling spot information system, parking assistance information, bridges and others. Bob (2007) expressed what can be termed as intelligent transport systems for sustainable development with the provisions of 
information systems for the vehicle, road users and transport infrastructures. From the policy point of view, researchers like

Høyer (2000), Black (2003), Black and Nijkamp (2002a) all examined sustainability in transportation from the perspectives that it must cater for infants and elderly people in the society, the cost of service provision and charges. Holden (2007) maintained that, sustainable transport system is different from sustainable mobility and the latter is preferred in North America while the former in Europe (Black, 2003). Furthermore, he explained that concept of sustainable transport can be view within the context of means of transport (vehicles), the infrastructure provisions and the energy systems that propel it. The advancement in technology, promotion of alternative energy and assessment of infrastructures are means of discovering sustainable developments in transport. There are views regarding transport policy for sustainable development on whether there is need to remove subsidy or not on infrastructure provision by government. Also, they opined that sustainable transport is the one that generates low carbon emission; reduce delay in traffic or absence of congestion, reduction in Sulphur emissions and reduction in travel times.

The aspirations and necessities of owing automobiles are critical to the survival of economic growth and developments. However, the concomitant effects of accidents, congestions, space accommodations in form of parking, land encroachment and environmental consequences warranted knowledge of traffic engineering, its planning, control and management. It is no longer sufficient to build roads of adequate structural strength as noted by Kadiyali (2002) to cater to the needs of vehicles; but equally is important that safety, efficient movement and comfort ability of movement are guaranteed. The road surface is that part of the road that the vehicle rides on and it is the most vulnerable part of the pavement. Primary function of this layer of pavement is to provide a comfortable riding surface for the traffic. In addition, it is expected to protect the layers beneath from the effects natural elements, as well as the disintegrating effects caused vehicles skidding and breaking on the roadway, hence it must be ensured that the surface materials are stable.

According to O'Flaharty (2006) expressed that; the number of road users increases based on the number of trips and household car ownerships. It was noted that, accidents on Nigerian roads are mostly caused by road conditions. EMCT (1995) further buttressed that, impacts as road transport has consequence of waste of time, waste of resources, caused delays, environmental pollution and loss of 2\% in Gross Domestic Product (GDP). Olaogun (2012)] expressed that, the problem with Nigerian roads is that government used to prefer to start new road projects than to maintain the existing ones. Dosunmu and Adepoju (2016) said that there is no relationship between money that is being generated from transport sector compared to the investments in the sector. O'Flaherty (2006) maintained that efficient allocation of scarce resources, economic efficiency and environmentally friendly transport system are fundamental to nation's developments. Apart from the introduction of Federal Road Maintenance Agency (FERMA), government also introduced Public Private Partnership (PPP) and Private Finance Initiative (PFI) to finance transport projects. Users' charge in form of toll pricing and concession were also introduced through Infrastructure Concession Regulatory Commission Act, 2005.

\subsection{Road maintenance}

Road maintenance can be described as the necessary action taken to repair, construct or upgrade roads in order to prevent it from damage to enhance smooth drive and negative consequence like accident, pollution, tear and wear of vehicles. Road maintenance involves activities like keeping the pavement, shoulders, drainage facilities, slopes and other structures PIARC (1994). Khandal (2009) espoused on the causes of road degradations like: action of traffic, ingress of water, oxidation process, inadequacies in design, specifications and construction standards and lack of adequate support from lower layers. Bleeding, cracking, deformation and disintegration are the signs of the road construction problems.

According to SANRAL (2004) three types of maintenance required for road maintenance are: urgent, periodic and routine maintenance. Urgent maintenance is a type of maintenance that requires immediate attention to prevent further and hazard effects that can cause irreparable loss. This type of maintenance can be required when something blocks the major road, necessity to widening the road or there is a collapse of culvert. Periodic maintenance is a type that deals with regular or interval maintenance usually to protect the structural integrity of the road. It can take the form of overlay, 
reconstruction and pavement. Routine maintenance is to allow daily pass ability and safety of the road to prevent and should be scheduled for instance in six months. Routine maintenance can be in form of patching, grass cutting, pothole repairs and filling of gravel or using asphalt or bitumen to perfect the smoothness of the road. The major issue in Nigeria is that, there are good plans and procedures on papers for road construction and maintenance but to adhere, enforce and implement are serious concerns. Decisions to be made both in design and operations in traffic engineering requires expertise knowledge in information technology, research methodology and analyses, modeling, simulations so as to improve traffic flow and safety with the support from enforcement and education.

In spite of the benefits of road transport; there are disadvantages in form of high costs of maintenance, capital required to construct the road, the nature and texture of soil and sometimes enormous resources for bridges because of water log, filling and requirements to circumvent natural topography. Road transport is a critical infrastructure for economic health as it untold hardship behoves condition of people with congestion, delay, the cost of movement and accessibility. According to National Planning Commission (2018), the structure of road maintenance and management is among the three tiers of government viz: Federal, State and Local Government. Regrettably, local governments that used to be responsible for arterial routes and Trunk C roads' had since failed to perform their responsibility perhaps as they are now taking orders from State governments. The reason for this is because, subservience of Local governments under the State connotes they do not have autonomy. The Nigerian road transport is the one of the overstressed mode of transport infrastructures in Nigeria and this partly due to inadequate and inefficient services of other complementing modes of transport services. Okunlola (2018) noted that, Federal Road Maintenance Agency (FERMA) was established to monitor and rehabilitate federal roads in Nigeria but, they lack the funding, equipment, innovation and motivation to execute their jobs. Virtually all processes of road construction used to pass through series of approval for allocation of funding and other statutory and not statutory procedures to pay contractors. Vintage Ltd (2017) noted that, FERMA only exist and known by those who created it and those who are not doing anything regarding themselves as staff of the agency. Almost all the states in Nigeria fashioned in line with the formation of FERMA's similar agencies yet; the roads are still not properly managed. Walter (2016)] observed that, the damage to Nigerian roads always start from cracking, potholes either by the edge of the road or at the centre.

Resultant effects of these roads are in incessant road accidents, traffic congestion, double cost if not triple of construction, increase in vehicle operating cost and frustration especially during the raining season. A lot of roads had been damaged as a result of lack of drainage. Apart from the availability of the traffic efficiency, the maintenance of the transport and infrastructure is one area that is not adequately monitored and the resultant effects are can be witnessed in the loss occasioned by reconstruction, accidents, wear and tear of vehicles among others. In developing economies, hardly will you see agency responsible for the maintenance of transportation infrastructure attending to decaying facilities until the issue gets out of hands. Erosion, bridges, covets, pedestrian crossings, to mention are few are not curtailed until the worst scenario happens. The sharp practices in project and contracts awards has made competent and reliable firm to also find means of reducing quality of service because of the "kickbacks" they are to give to people who had given them the contracts. In essence, the mixture, quality of materials including labor are all doctored to reduce overall costs of project to maximize the profit to be generated at the expense of millions of life that may be lost in the long run.

The method of road project finance where "kickbacks" dictates the contractor or the construction company cannot produce sustainable development. Many roads in Nigeria like Ibadan- Ilorin road had been awarded for dualization since 1999 during President Olusegun Obasanjo's regime to be completed in 5 years; and surprisingly the construction is still on-going. Worst issue here is that most works executed initially must have been washed away by erosion or heavy trucks plying the route. It is always a case of begin again when roads are not constructed according to schedule. Sally and Natalya (2005) said that postponing maintenance or construction cost increases both direct and indirect costs. If defect on the road noticed and neglected; the entire section of the road may fail completely and requiring reconstruction at three time or more of the initial cost. SANRAL (2004) explained that repair cost for road construction rises to six times the maintenance cost when you neglect road maintenance for three years and eighteen times after five years of neglect. O'Flaharty (2006) noted that both preventive and corrective maintenance must be observed for sustainable road construction. To this end, this paper has been set out to answer the following research questions: 
a) Why governments at all levels cannot construct/repair roads as was the case in the past?

b) What are the challenges of road construction companies in Nigeria?

c) What are the effects of bad roads on national development?

The gap has identified by this research is mainly in the difference between modern rapid technology advancement in road construction/ repairs and the slow progress of resources moneywasting-long-term construction system in Nigeria. More so, the qualities of roads built in the past differ from recent ones

\section{Materials and methodology}

South-western geopolitical zone of Nigeria comprises Ogun State, Lagos State, Osun State, Oyo State, Ekiti State and Ondo State. The ministry of works and Transport, Ibadan was selected based on the fact that, it was the center of old western region secretariat. The respondents sampled are the staff of two construction companies operating prominently in the western states: Reynolds Construction Company (RCC) and China Civil Engineering Construction Company (CCECC). Interview, purposive and incidental sampling techniques were used to select 150 respondents across the ministry of works and Transport, Ibadan and the selected construction companies within the region. There are arrays of opinions regarding the question on why government cannot properly finance roads in Nigeria. The numerous data gathered on this question can be best identified to factors listed in the next section. Using open-ended questionnaire as data collection instrument, about 20 site supervisors provided their responses and the various departments including electrical, civil, special projects and mechanical at the ministry of works and transport responded.

\section{Results and discussion}

The various responses gathered from the respondents are synchronized as identified in the following factors as the reasons the government could not construct and repair roads in South-Western Nigeria.

1. Inadequate fund

IDF

2. Wrong contractors

WCT

3. Diversion of funds

DFD

4. Inadequate machinery

IDM

5. Corruption

CRP

6. Lack of accountability

LCB

7. Incompetent personnel

ICP

8. Joint allocation for state and local government JAG

9. Lack of succession in governance LSG

10. Conflict of ownership between federal and state roads CFS

11. Inadequate management ethics IME

12. Wrong priority of government WPG

13. There are many roads MRD

14. Daily urbanization DUB

15. Lack of collaboration with investors LCI

16. Use of foreign contractors UFC

17. Roads not commeasuring with level of service RNC

18. Wrong season for construction RSC

19. Over-dependence on road ODO

20. Topography TPG

The table 1 below shows the sampling adequacy for the principal component analysis. The sample adequacy is goo with significance $\mathrm{p}<0.05$ and Kaiser-Meyer Measure is above 0.5. 
Table 1: KMO and Bartlett's Test

Kaiser-Meyer-Olkin Measure of Sampling Adequacy.

Bartlett's Test of Sphericity

Approx. Chi-Square

.533

Df

371.443

190

Source: Output from the analysis (2019)

.000

The communalities of the identified factors are shown below. The communalities below 0.4 are not to be considered as factors responsible for why governments at all levels cannot construct/repair roads as depicted in table 2 .

\begin{tabular}{lcc} 
Table 2: Communalities of factors & & \\
\hline \multicolumn{1}{c}{ Communalities } & Initial & Extraction \\
\hline Inadequate funds & 1.000 & .810 \\
Wrong contractors & 1.000 & .587 \\
Diversion of funds & 1.000 & .801 \\
Inadequate machinery & 1.000 & .287 \\
Corruption & 1.000 & .639 \\
Lack of accountability & 1.000 & .668 \\
Incompetent personnel & 1.000 & .721 \\
Joint allocation for state \&LG & 1.000 & .681 \\
Lack of succession in governance & 1.000 & .305 \\
Conflict of ownership btw state and LG & 1.000 & .522 \\
Inadequate management ethics & 1.000 & .665 \\
Wrong priority of govt & 1.000 & .531 \\
Many roads & 1.000 & .588 \\
Daily urbanization & 1.000 & .657 \\
Lack of collaboration with investors & 1.000 & .682 \\
Use of foreign contractors & 1.000 & .672 \\
Construction not measuring with level of & 1.000 & .574 \\
service & 1.000 & .605 \\
Wrong season for construction & 1.000 & .703 \\
Over dependence on road & 1.000 & .673 \\
Topography & & \\
\hline Exogn
\end{tabular}

Extraction Method: Principal Component Analysis.

Source: Output from the analysis (2019)

Examining the communalities, only two factors should not be considered in this analysis as they have values below 0.4 . The factors are the inadequate machinery with the value of 0.287 and lack of succession in governance with the value of 0.305 .

Table 3 shows the rotated component matrix which indicates the components of the factors identified.

\begin{tabular}{|c|c|c|c|c|c|c|c|c|}
\hline \multirow[b]{3}{*}{ Inadequate funds } & \multicolumn{8}{|c|}{ Component } \\
\hline & 1 & 2 & 3 & 4 & 5 & 6 & 7 & 8 \\
\hline & .865 & & -.149 & -.121 & & & & -.102 \\
\hline Wrong contractors & -184 & -.105 & .582 & -.220 & -.295 & 111 & -.122 & -.200 \\
\hline Diversion of funds & .864 & & & & & .110 & -.178 & \\
\hline Inadequate machinery & .202 & .170 & -.304 & -.231 & & .242 & & \\
\hline Corruption & .156 & & -.536 & .409 & -.122 & -.229 & .245 & -166 \\
\hline Lack of accountability & -.309 & .702 & & -.109 & .174 & -107 & & -.116 \\
\hline Incompetent personnel & .120 & & .776 & .155 & .138 & -.181 & .153 & \\
\hline $\begin{array}{l}\text { Joint allocation for state } \\
\& \text { LG }\end{array}$ & & -.383 & -.183 & -.196 & .577 & -.128 & .254 & -.220 \\
\hline $\begin{array}{l}\text { Lack of succession in } \\
\text { governance }\end{array}$ & & .216 & & & & .449 & -.183 & \\
\hline
\end{tabular}




\begin{tabular}{|c|c|c|c|c|c|c|c|c|}
\hline Conflict of ownership & & .560 & & & & .223 & & -.378 \\
\hline $\begin{array}{l}\text { Inadequate } \\
\text { management ethics }\end{array}$ & & & -.102 & & & & & .804 \\
\hline Wrong priority of govt & -.123 & 122 & & & & & .703 & \\
\hline $\begin{array}{l}\text { Many roads } \\
\text { Daily urbanization }\end{array}$ & -.134 & & & & $\begin{array}{l}-.186 \\
.800\end{array}$ & .695 & & .194 \\
\hline $\begin{array}{l}\text { Lack of collaboration } \\
\text { with investors }\end{array}$ & & .790 & & & & .136 & & .127 \\
\hline $\begin{array}{l}\text { Use of foreign } \\
\text { contractors }\end{array}$ & -.153 & -.117 & & .699 & .117 & .276 & -.163 & -.160 \\
\hline $\begin{array}{l}\text { Construction not } \\
\text { measuring with level of } \\
\text { service }\end{array}$ & & -.144 & -.114 & & -.554 & & .463 & \\
\hline $\begin{array}{l}\text { Wrong season for } \\
\text { construction }\end{array}$ & & & .320 & & & & .535 & .437 \\
\hline $\begin{array}{l}\text { Over dependence on } \\
\text { road }\end{array}$ & & & & .805 & & -.153 & & .132 \\
\hline Topography & -.252 & & & & & -.662 & -.382 & .114 \\
\hline
\end{tabular}

Extraction Method: Principal Component Analysis.

Rotation Method: Varimax with Kaiser Normalization.

a. Rotation converged in 15 iterations.

Extracting the principal component, eight components were extracted. For component 1, inadequate fund and diversion of funds with 0.865 and 0.864 respectively are the only factors to be picked. Component 2 shows that, lack of accountability, conflict of ownership between State and Local governments and lack of collaboration with values of $0.702,0.506$ and 0.790 respectively. Component 3 shows that; wrong contractors and incompetent personnel are the factors with 0.583 and 0.776 respectively. Use of foreign contractors and over dependence on road is another factor in component 4 with 0.699 and 0.805 values respectively. The fifth component has to do with joint allocation between state and local government with value of 0.577 , daily urbanization with 0.800 and construction not measuring with level of service with 0.554 . There are too many roads and topography formed component six with 0.695 and -0.662 respectively. Government priority and wrong season for construction formed component seven with 0.703 and 0.535 values respectively. The eighth component shows that lack of management ethics is a factor that is responsible for why government cannot construct/repair roads in Nigeria with 0.804 value.

The summary of the components can be as follows:
a) Fund
b) Separation of power and lack of investors
c) Competence of contractor
d) Over dependence on road
e) Urbanization
f) Topography
g) Timing of construction
h) Management ethics.

All these factors are to be considered if quality roads are to be guaranteed in the south-western Nigeria. Analyzing the challenges of the construction companies in South-Western Nigeria, the respondents' responses have been summarized in the Figure 1 below descriptively. 
Figure 1: Challenges of road construction companies

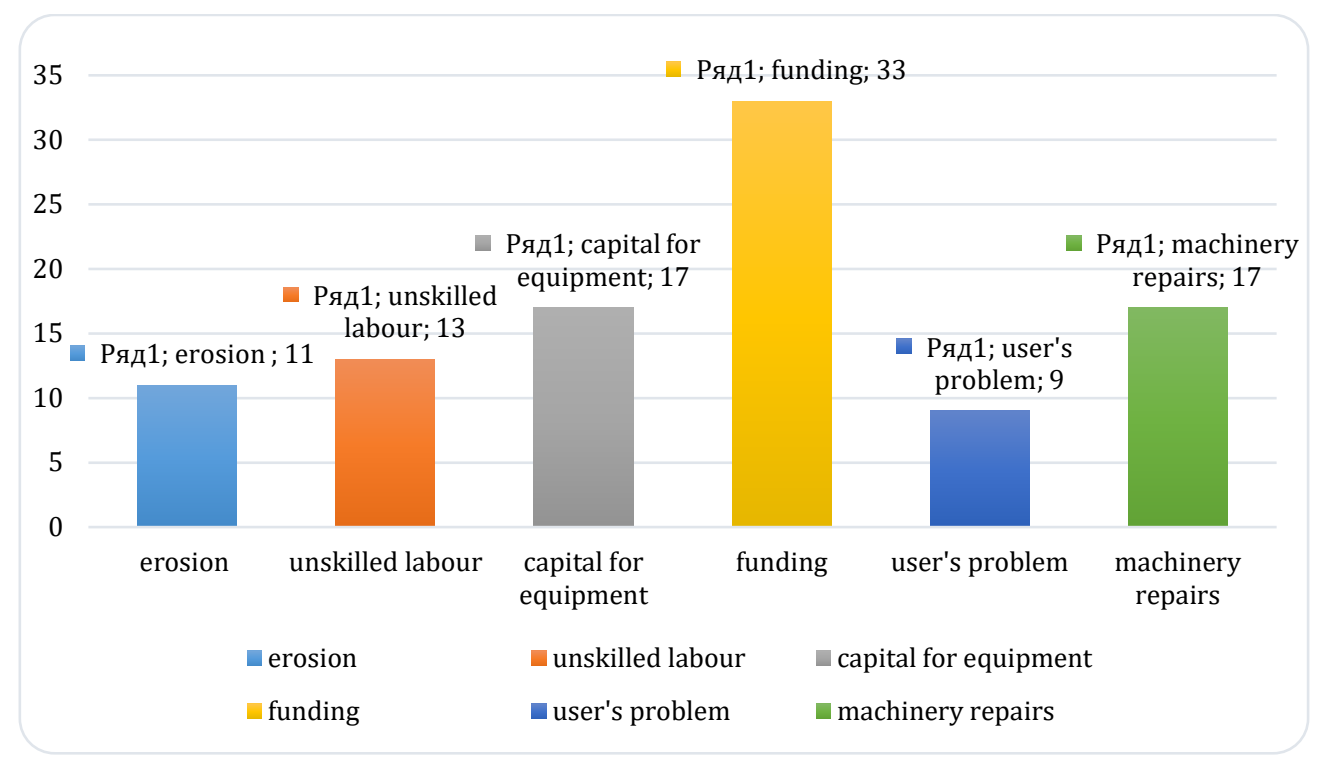

The major challenge as indicated by the figure 1 is funding which indicates $33 \%$, the next challenge is capital for equipment and machinery repairs with $17 \%$ each respectively. The companies also face the challenges from unskilled labor with the bar chart indication of $13 \%$, erosion used to challenge the companies also with the chart showing $11 \%$. The construction companies noted that, they used to have challenges from the road users which is about $9 \%$ of their challenges. The funding from the government that used to be taking a lot of time is what the respondents described as the major problem. The respondents noted that, the equipment being used by the construction companies are very expensive and to repair they are very costly and difficult which is why the two are having the same percentage $(17 \%)$.

The Figure 2 below shows the pie chart of the effect of bad roads on national development. The responses of the sampled respondents shows that, bad roads are the result of crashes with $27 \%$, the maintenance cost is the second with $21 \%$, bad roads contribute to capital flight with $17 \%$. Passenger discomfort has $14 \%$, high transportation cost has $11 \%$ and driver's fatigue has $10 \%$.

\section{Figure 2: Effects of bad roads on national development}

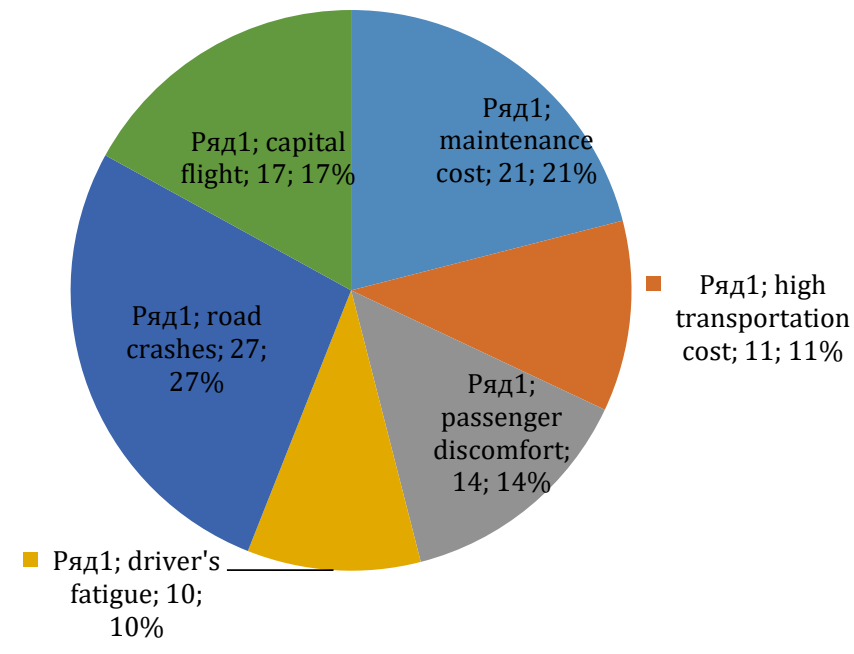

\section{Conclusion and recommendations}

The findings from the results have shown that there are factors that should be observed if the construction and maintenance of roads are to achieve sustainable development in south-western 
Nigeria. Apart from these factors, construction companies also have their challenges. The challenges of the construction companies and the funding most especially from government must be examined before embarking on any construction project. Government needs to incorporate investors in financing road construction projects. Since funding is the major challenge, there is need for government to seek how to manage funds that are generated through road transport like; licensing, roadworthiness, vehicle licensing, and user's charge or toll pricing to finance road transport projects. It will be better for government to always ensure that projects of road transport construction and maintenance are of quality and executed with the allocated time fame. Also of note is the season, because sometimes, when road projects are not funded properly, the work done during a particular period and is being stopped will amount to double cost by the time it will start again. Road construction project are to be monitored and supervised by the government and the construction companies must give guarantee on the number of years for the usage of the road as it is being practiced in developed economy. There is also need for the country as a whole to engage indigenous construction companies in road construction projects. There is need for separate of power between state and local government as indirectly the autonomy of Local government as a tier of government is real in Nigeria again occasioned by their subservience to State government arising from their allocation being given to the States. The Local government will not be able to construct nor repair roads because their fund is determined by State governments. There is need also for government to standardize procedure for road construction projects, penalty, quality, usage and rehabilitation in order to achieve sustainable development.

Roads are built mostly with public funds. However, public funds are not easily accessed and must be captured by budgets to be released for road constructions or repairs. Road maintenance involves coordination of unrelated activities that must be integrated together. Looking at the past records of road construction history in the South-western Nigeria; the management, planning, construction and rehabilitation of roads are carried out by respective local government at the Local Government levels and ministry of Works and Transport/Housing as the case may be for the State roads. Recently, governments have decided to outsource for construction companies to facilitate rapid construction process.

\section{Citation information}

Adepoju, 0. 0. (2021). Analysis of road transportation infrastructure construction and maintenance for sustainable development in South-Western Nigeria. Journal of Sustainable Development of Transport and Logistics, 6(1), 49-58. doi:10.14254/jsdtl.2021.6-1.4

\section{References}

Akindare, 0. (2018). Advancement in road building technology may be the intervention Nigeria's road Needs. Nation.

Black, W. R. (2003). Transportation. A geographical analysis. New York/London: The Guilford Press.

Black, W. R., \& Nijkamp, P. (2002). Introduction: Pathways to sustainable transport and basic themes. Social Change and Sustainable Transport; Black, WR, Nijkamp, P., Eds.

Burningham, S., \& Stankevich, N. (2005). Why road maintenance is important and how to get it done (No. 11779). The World Bank.

Central Bank of Nigeria. (2002). Annual report and statement of account for the year ended 31st December, 2001, CBN, Lagos, April.

Danladi, S. M., Oluwatosin, A., \& Amaechi, C. V (2013). Challenges of road pavement failure in Nigeria. In Proceeding for National Conference on Road Pavement Failure in Nigeria, NBRRI A Proceedings of National Conference on Road Pavement Failure in Nigeria, Abuja, 7th -9th May 2013.

Dosunmu, V. A., \& Adepoju, O. O. (2016). Appraisal of transport infrastructure finance for sustainable development in Nigeria. International Journal of Science and Research, 2319-1764.

EMCT. (1995). Urban travel and sustainable development. Paris.

Emiedafe, W. (2016). Road maintenance: 4 critical functions of road maintenance in Nigeria sapient vendors. Retrieved from www.saplentventdors.com. 
Ezenwa, A. O. (1986). Trends and characteristics of road traffic accidents in Nigeria. Journal of the Royal Society of Health, 106(1), 27-29.

Filani, M. O. (1993). Transport and rural development in Nigeria. Journal of Transport Geography, 1(4), 248-254.

Hamzat, Y. (2016). An assessment of road transport infrastructure development in Kaduna State, Nigeria. Unpublished master thesis, Department of Geography, Faculty of Science, Amadu Bello University, Zaria.

Holden, E. (2007). Everyday and Leisure-Time Travel in the EU. Ashgate.

Høyer, K. G. (1999). Sustainable mobility: The concept and its implications (Doctoral dissertation, Institute of Environment, Technology and Society, Roskilde University Centre).

Kadiyali, L. R. (2002). Traffic engineering and transportation planning. Khanna books Publishing Ltd, India.

Khandal, M. (2009). Maintenance of infrastructure - case study of highway sector. Unpublished presentation to the students of Transport Management, LAUTECH, Ogbomoso, Nigeria.

National Planning Commission Bill. (2018).

Ndikom, O. B. (2009). Elements of transport management. Bimco.

O'Flaherty, C. A. (2006). Traffic and transportation engineering. Elsevier.

Olaogun, O. B. (2012). Highway and traffic engineering - a case study of Nigerian roads. An unpublished paper, Department of Transport Management, Ladoke Akintola University of Technology, Ogbomoso, Nigeria.

Permanent International Association of Road Congresses (PIARC). PIARC (World Road Association). (1994). International Road Maintenance Handbook: Practical Guidelines for Rural Road Maintenance, I of IV. Roadside Areas and Drainage. Financed and coordinated by ODA and TRL.

SANRAL (South African National Road Agency Ltd). (2004). Annual report 2004: sustainability report. Pretoria, South Africa.

Somuyiwa, A. O., \& Onifade, O. A. (2020). Enhancing sustainable road transport safety practices.

UNCTAD. (2017). Road Safety Considerations in support of 2030 agenda for sustainable development.

Vintage Ltd. (2017). FERMA urged to complete Third Mainland Bridge repairs The Nation, February 1, 2017.

Walker, G. (1959). Traffic and transport in Nigeria. The Example of an Under Developed Tropical Territory. Her Majestey's Stationary Office, London.

Williams, B. (2008). Intelligent transport systems standards. Artech House.

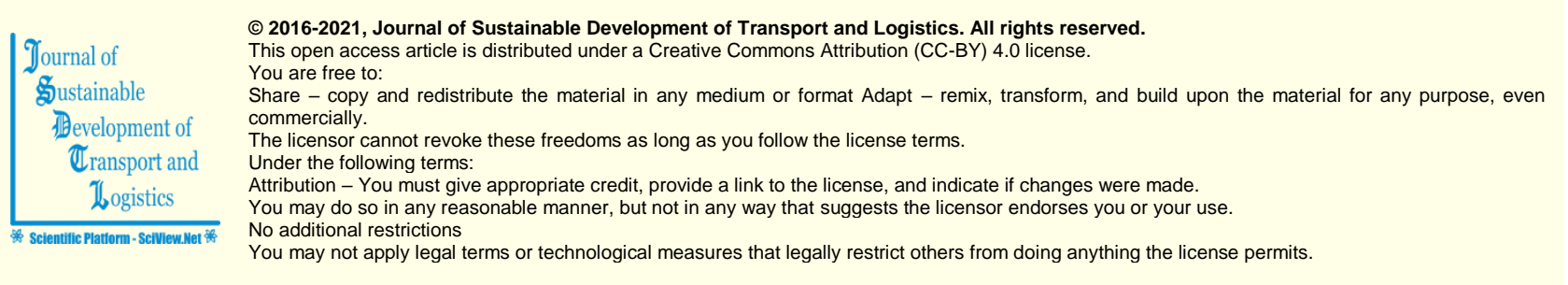

Journal of Sustainable Development of Transport and Logistics (ISSN: 2520-2979) is published by Scientific Publishing House "CSR", Poland, EU and Scientific Publishing House "SciView", Poland, EU

Publishing with JSDTL ensures:

- Immediate, universal access to your article on publication

- High visibility and discoverability via the JSDTL website

- Rapid publication

- Guaranteed legacy preservation of your article

- Discounts and waivers for authors in developing regions

Submit your manuscript to a JSDTL at https://jsdtl.sciview.net/ or submit.jsdt|@sciview.net 